\title{
La militarización de las celebraciones públicas en el Chile de los Borbones y la Independencia
}

\author{
Jaime VALenzuela MárqueZ \\ Pontificia Universidad Católica de Chile \\ jvalenzm@uc.cl
}

Recepción: 11 de noviembre de 2010 / Revisión: 3 de abril de 2011

Aceptación: 13 de junio de 2011 / Publicación: diciembre de 2011

\section{RESUMEN}

El artículo explora el creciente despliegue de lo militar en el Chile del siglo XVIII, inserto en un proceso que emanaba desde la propia España y abarcaba todos los dominios americanos del período. Luego se analiza la evolución de este proceso durante la coyuntura de la independencia, tanto a nivel de la actividad propiamente castrense como de la administración política y de su revestimiento simbólico litúrgico, poniendo especial énfasis en el estudio de las celebraciones públicas.

Palabras clave: celebraciones públicas, militares, Borbones, independencia, Chile, siglo XVIII.

\section{The militarization of public celebrations in Bourbon and Independent Chile}

\begin{abstract}
This article examines the increasing deployment of army and military symbols and practices in eighteenth-century Chile. It then traces the evolution of this process during the period of independence from Spain, by focusing on the increasing military activity of the early nineteenth century, and the transformations experienced by the political administration and their symbolic liturgical practices under the nation.
\end{abstract}

Keywords: Public Celebrations, Militaries, Bourbons, Independence, Chile, 18th. Century.

SUMARIO: 1. Un viejo actor con nueva mística. 2. Militarización de la ciudad de Santiago. 3. Militarización de las celebraciones. 4. Sonoridad castrense y campanas eclesiásticas. 5. La independencia consolida la hegemonía. 6. Referencias bibliográficas.

\section{UN VIEJO ACTOR CON NUEVA MÍSTICA}

Una de las señales distintivas del régimen borbónico español fue la reorganización militar originada por las urgencias bélicas de su política exterior. De hecho, como analiza Christon Archer, se puede establecer una línea divisoria bastante clara en la historia militar de Hispanoamérica durante la década de 1760. Antes de esa fecha no se necesitaban grandes fuerzas militares para defender las diversas provincias o para mantener la calma interna, puesto que bastaban las milicias urbanas. El asalto británico a La Habana de 1762 -en el marco de la llamada "Guerra de los Siete Años" (1756-1763)- provocó la alteración del antiguo sistema defensivo costero y el diseño de una política de creación de regimientos provinciales, batallones y compañías de 
infantería, caballería y dragones en todo el continente. Estos cambios se aceleraron por la extensión de la amenaza inglesa hacia la América meridional y se refrendaron al finalizar el siglo por la emergencia de la Francia revolucionaria y de las guerras que le declaró España en $1793^{1}$.

Aunque algunas autoridades coloniales habían introducido ciertas reformas con anterioridad, lo cierto es que no había existido una revisión de fondo de la política militar imperial. La ocupación cubana abrió una serie de debates y acciones que implicaron una presencia militar en Hispanoamérica cada vez más numerosa y poderosa, tanto de tropas regulares como de milicias "disciplinadas"2. Reformas que incluyeron la creación de intendencias y la subdivisión administrativa de las jurisdicciones virreinales existentes ${ }^{3}$.

Estos cambios no sólo tuvieron impacto a nivel del número de efectivos o de la infraestructura defensiva. Sus efectos también se pudieron observar en el plano propiamente político, como sucedió en Chile, por ejemplo, donde, al mismo tiempo que el sistema imperial puso énfasis en el cargo jurídico-administrativo del representante real, como Presidente de la Real Audiencia, también se reforzó su título paralelo y tradicional de Capitán General ${ }^{4}$. Este refuerzo acompañó la nueva orientación de la profesión militar, junto con la guerra, al "progreso" material de las colonias, en cuyos cánones la ingeniería militar se encontraba íntimamente ligada a la planificación y la construcción de obras públicas ${ }^{5}$.

En efecto, la monarquía "administrativa" que se desarrolla con los Borbones conlleva una participación importante y creciente de los militares en el gobierno imperial, con una faceta muy ligada al pragmatismo utilitario, convirtiéndose en un soporte fundamental de la explotación económica que estaba desplegando el renovado sistema colonial en América ${ }^{6}$.

${ }^{1}$ Archer, 1993, p. 217; Chauca, 2005.

2 Detrás de las "milicias disciplinadas" está la idea de crear cuerpos homologables en armas, uniformes, entrenamiento y mandos en todo el Imperio; pero eso mismo hace que convivan con las milicias concejiles tradicionales. Como en este caso, se trata de civiles integrados a cuerpos militares no profesionales, que gozan de fuero militar y, en el caso de los oficiales, tienen el privilegio de portar armas y usar uniformes en contextos civiles. Cfr. McAlister, 1957; Kuethe, 2005.

3 Archer, 1993, p. 228; Góngora, 1998, p. 171. Para un análisis monográfico sobre el auge del ejército y la militarización de Hispanoamérica en la segunda mitad del siglo XVIII, y sobre el posicionamiento de lo militar en los distintos niveles sociales y políticos coloniales, véanse los trabajos de Kuethe, 1978; Campbell, 1978; Archer, 1983; Borja Medina, 1984; Gascón, 1993, donde se entregan abundantes referencias bibliográficas sobre los temas tratados en este capítulo. Para Chile, véase también el reciente trabajo de Ossa SANTA Cruz, [inédito].

${ }^{4}$ Gálvez, 1999, p. 258.

${ }^{5}$ Cfr. Marchena Fernández, 1977. La instrucción propiamente militar, de hecho, requería conocimientos de balística y operaciones elementales de cálculo. "Todo artillero debía ser aritmético", señalaban algunos teóricos ya desde comienzos del siglo anterior. Siendo gobernador de Chile, por cierto, Manuel de Amat dispuso que varios cadetes asistiesen a estudiar matemáticas en la Real Universidad de San Felipe: Informe del gobernador al rey. Santiago, 29-X-1758. Biblioteca Nacional, Biblioteca Medina, Manuscritos (en adelante, BN. BM. Mss.), 189, leg. 4343. Para referencias comparativas sobre este tema y el "espíritu" de la época, véanse los trabajos de CAPEL, 1983 y 2005; RAGAS, 2004, p. 217; LeÓN García, 2006.

${ }^{6}$ Cfr. los textos clásicos de Brading, 1971 y 1991. 
Aportando su organización institucional y sus capacidades técnicas, el ejército se alza, entonces, como un nuevo pilar de apoyo del Estado absolutista y un símbolo del orden racional y de la organización jerárquica y corporativa, además de reforzar su función tradicional como canal de movilidad e integración social. En el marco de este ideal burocrático-castrense, por lo tanto, no debe extrañar que en Chile el cargo de Capitán General apareciese en asociada complicidad con el de Intendente; funcionario, este último, que habitualmente no tendrá formación jurídica, sino que será reclutado desde el ejército o desde las nuevas ramas del servicio civil creadas en el siglo XVIII ${ }^{7}$.

Surge entonces la figura del militar-administrador y del militar-ingeniero, en contraposición al militar-guerrero, en lo que algunos historiadores han calificado como una "militarización del Estado" e, incluso, como una "militarización de la ciencia" en la España borbónica. Francisco Andújar Castillo retrata así el remozado enfrentamiento que se produjo entre togados y militares, dada la creciente influencia de estos últimos en los asuntos de gobierno ${ }^{8}$.

Los militares de carrera también se transforman en un renovado instrumento burocrático, pues garantizan el orden público mejor que los letrados y cortesanos, favorecidos durante la centuria precedente, y la monarquía los ve con la firmeza, honestidad y eficiencia necesarias para cumplir con el proceso de reformas. Lo que caracterizará en definitiva a este militar-político-administrador de alto grado será la sumatoria de la impronta nobiliaria, de la nominación en empleos burocráticos y de la pertenencia al estamento militar profesional; ascenso que se consolida cuando se une con el progresismo ilustrado, a partir de la figura del ingeniero militar asociado a las obras públicas del Estado 9 .

Ahora bien, es necesario matizar este proceso en el caso de colonias periféricas como Chile, donde difícilmente estaremos frente a una militarización efectiva y generalizada, ni menos ante un "Estado militarizado" -como concluye también Archer para el caso de México-; para el caso chileno, al menos, podríamos hablar más bien de una "militarización simbólica", donde si bien están presentes los aspectos vistos en los párrafos anteriores, como la ideología subyacente, los modelos de organización, las formas y jerarquías específicas, etc., todo indica que al parecer no llegará a cristalizarse como una estructura efectiva y definitiva como lo preveían las autoridades imperiales. Esta advertencia deberemos tenerla presente, por cierto, a lo largo de nuestro análisis.

\section{MILITARIZACIÓN DE LA CIUDAD DE SANTIAGO}

La reorganización militar de Chile comenzó en 1753, aunque sería en 1778, bajo el gobierno de Agustín de Jáuregui, cuando se haría una reforma radical que dio una nueva distribución a los cuerpos de acuerdo a las Ordenanzas de Su Majestad para el

\footnotetext{
${ }^{7}$ GóngORA, 1998, p. 175.

${ }^{8}$ Andújar Castillo, 1991.

${ }^{9}$ Ibídem.
} 
régimen de disciplina, subordinación y servicios de sus exércitos (1768). Éstas disponían el reagrupamiento de las fuerzas con la participación de cuerpos de infantería, caballería y dragones, y con el apoyo de los cabildos y los gremios ${ }^{10}$. La reforma de 1778 contempló el establecimiento de dos cuerpos de caballería: uno en Concepción -los "Dragones de la Frontera"- y otro en Santiago -los "Dragones de la Reina Luisa", con una compañía de 50 hombres- ${ }^{11}$.

Los dragones santiaguinos, en todo caso, ya habían sido creados por el gobernador Manuel de Amat y Juniet en 1758 con el objetivo coyuntural de reprimir un motín de los reos de la cárcel, cuya justificación más profunda iba de la mano de la creciente inmigración rural popular que afectaba a la ciudad que se acompañó de un aumento sostenido de la delincuencia urbana ${ }^{12}$. Su destacamento, cuyo cuartel se encontraba al costado del palacio del gobernador, servía como escolta de la máxima autoridad, resguardo para los edificios públicos y apoyo represivo de la administración urbana de justicia ${ }^{13}$. En todo caso, desde un comienzo se le quiso diseñar como un destacamento de alto nivel que respondiese a los criterios de eficiencia y disciplina que exigían las circunstancias, con un espíritu acorde con las nuevas concepciones ilustradas del ejército. Este carácter "elitista" además se daba por su vinculación con la figura del gobernador. De ahí que todos sus miembros fuesen exclusivamente españoles, estuviesen bien y regularmente pagados, y recibieran -incluidos los soldados- el trato de "don" 14 .

La milicia también vivió un proceso de reorganización durante la segunda mitad del siglo, pues ya en 1759 el gobernador Amat, paralelamente a la constitución del cuerpo de Dragones, había expedido una ordenanza orientándola a la autodefensa regional que se ubicaba en el marco de las reformas que se experimentaban a nivel continental ${ }^{15}$. Algunos años después, de hecho, un bando del gobernador Guill y Gonzaga dispondrá una serie de ordenamientos defensivos y de prohibiciones a los súbditos de Santiago, en lo que, a juicio de Leonardo León, constituiría una manera de materializar la guerra lejana en la realidad local. La movilización miliciana contribuiría,

${ }^{10}$ Marchena Fernández, 1992.

11 Estos dragones serán el único cuerpo militar pagado de la diócesis capitalina, junto con los artilleros de Valparaíso: Carta del obispo al ministro de Indias. Santiago, 29-I-1787. Archivo General de Indias (en adelante, AGI). Chile, 460; BArros AranA, 1999-2005, VII, P. 247. En Lima, a mediados del siglo XVIII, el virrey contaba para el resguardo de la persona, "autoridad del empleo y ostentación de la superioridad", con dos compañías de guardias: una de caballería, con 160 hombres, y otra de infantería, con 50 alabarderos: JUAN y ULLOA, 1748, III, p. 52.

${ }^{12}$ Carta del Cabildo al rey. Santiago, 29-X-1758. BN. BM. Mss. 189, leg. 4342; LEÓn, 2000. No está demás subrayar la importancia central que tiene Amat en la "militarización" de Santiago; actitud que luego repetiría siendo virrey del Perú, frente a amenazas externas -de ingleses y franceses- e internas -revueltas en el interior del país-, y donde algunas de sus manifestaciones más evidentes serían los desfiles permanentes: Cervilla LozADA, 2004, p. 51; Ragas, 2004, pp. 211 y 213.

13 Al respecto, véase: carta del gobernador al rey. Santiago, 28-X-1758. BN. BM. Mss. 189, leg. 4341; Real Cédula. Madrid, 12-X-1760. BN. BM. Mss. 328, leg. 453; SAnta Cruz, Juan José de. "Noticia de Santiago". Santiago, 8-IV-1790. Reproducido en Sagredo BaEza - GonzÁlez LeIva, 2004, pp. 466 y 478.

${ }^{14}$ De Ramón, 1992, pp. 129-130; Allendesalazar, 1962, p. 127; Undurraga, 2008, 2ªrte, cap. 2.

15 Vergara, 1993, I, p. 48. 
con ello, a "crear un ethos de lealtad, obediencia y disciplina", un clima psicológico de "patriotismo" que alimentaría la noción de pertenencia a la comunidad imperial y, al mismo tiempo, las condiciones para desplegar un eventual control de carácter policial en el país. Sin ir más lejos, en el mismo bando citado se convocaba a las milicias existentes para una revista general que haría el gobernador en la plaza de Santiago, "a fin de destinarlos, siendo necesario, en lo que pueda ocurrir"16.

Lo cierto es que la situación externa se vio potenciada por la coyuntura militar interna que se vivió en la frontera mapuche, desencadenada a raíz de una rebelión indígena en el quinquenio 1765-1770 y de algunos enfrentamientos y hostilidades en 1776. Además, las incursiones pehuenches para robar ganado a través de los boquetes cordilleranos de la zona central llegaron incluso a amenazar la propia capital en $1779^{17}$. En medio de esta coyuntura, el gobernador Jáuregui preparó una reforma de las milicias de la capital con el fin de darles mayor orden, eficiencia y distinción. Del batallón de ocho compañías de caballería, integradas por los hispanocriollos de la ciudad -donde cada compañía tenía como capitán a un "noble"-, la autoridad formó dos regimientos, de 12 compañías cada uno, divididas en cuatro escuadras, "con todo el estado mayor y oficiales nobles de la ciudad". Así nacieron, a mediados de 1777, los regimientos de caballería denominados "El Príncipe" y "La Princesa", cuya oficialidad provenía exclusivamente de los grupos más acomodados de la sociedad capitalina, al igual que ocurría en todos los otros cuerpos milicianos; la tropa, por su parte, comprendía al común de los hombres de entre 15 y 45 años ${ }^{18}$.

Estas condiciones sociales, que más tarde serían avaladas por el "Reglamento para las Milicias de Infantería y Caballería de Cuba" (1769) -aplicado a todo el continente desde 1791- permitieron reavivar el papel simbólico que venía jugando el universo miliciano desde el siglo anterior. Es decir, un espacio "ennoblecedor" donde se alimentaba el prestigio "caballeresco" del patriciado tradicional -para el caso de la caballería- y de grupos emergentes y arribistas -en la oficialidad de infantería- ${ }^{19}$.

Por toda América los nuevos cuerpos milicianos, organizados con la apariencia de tropas de línea y con su oficialidad revestida con vistosos uniformes y fuero corporativo, fueron confirmados entonces como canales de movilidad y refrendación social ${ }^{20}$. De hecho, sus grados siguieron siendo enarbolados por sus detentores como signo de prestigio y correlato simbólico del rango social y la riqueza, llegando incluso a solicitar el título honorario de cadetes para sus hijos cuando estos aún eran niños ${ }^{21}$.

Con respecto a las milicias de infantería, también en 1777 se creaba un regimiento denominado "del Rey"22, al tiempo que se refundaba el batallón "del Comercio",

${ }^{16}$ Citado en LeÓn, 1998, pp. 64-65.

${ }^{17}$ Barros Arana, 1999-2005, VI, p. 264; Villalobos, 1995, p. 38.

${ }^{18} \mathrm{La}$ información sobre las milicias que recogemos en este párrafo y en los siguientes ha sido obtenida en: Barros Arana, 1999-2005, VI, p. 264; Cartas del gobernador al rey. Santiago, 6-VIII-1777 y 3-X-1777. BN. BM. Mss. 197, legs. 4728 y 4732 (respectivamente); MedinA, 1970, I, p. 281; ALLENDESALAZAR, 1962, pp. 112-113, 117-118; VERGARA, 1993, I, pp. 52-53.

19 Valenzuela Márquez, 2001, pp. 337 y ss.

20 Cfr. Archer, 1993, p. 245.

${ }^{21}$ Barros Arana, 1999-2005, VI, p. 265; Hernández Ponce, 1984.

22 En 1779 este regimiento fue ampliado con una nueva compañía “de Cazadores de Infante- 
destinado a los vecinos que se dedicaban a dicha actividad. Una de las compañías de este último, fundada en tiempos de Amat como "Compañía de Nobles", había servido como escolta personal de los gobernadores en las celebraciones públicas hasta su disolución, a comienzos de la década de 1770 . De ahí que también se le conociese como "Privilegiada del Señor Presidente" y que todos sus integrantes fuesen miembros de las élites ${ }^{23}$. En todo caso, si bien este destacamento se reunía en forma expresa para acompañar al gobernante en las caminatas oficiales -como la que realizaba entre el palacio y la catedral para asistir a alguna fiesta religiosa "de tabla"-, la escolta formal y permanente de la autoridad, en trayectos a caballo o carruaje, era una compañía de Dragones ${ }^{24}$. Esta compañía vio refrendada su posición tras la disolución de la Compañía de Nobles, que guardó concordancia con el espíritu más político-administrativo asumido tanto por el propio gobernador como por el mundo castrense profesional.

Por último, también fueron reorganizadas las milicias de los mulatos de la capital, cuyos antecedentes podemos encontrarlos fragmentariamente en el siglo XVII y, ya en forma más sistemática, desde 1723, cuando el gobernador Cano de Aponte formó en Santiago dos compañías de "horros", con un total de 250 individuos ${ }^{25}$. En 1759 y casi juntamente con la creación de los Dragones de la Reina, el gobernador Amat había aumentando a 300 sus efectivos, incluyendo a pardos, mulatos y negros libres y formando una flamante sección de artilleros que, como veremos, será convocada para llevar a cabo las detonaciones que acompasaban las liturgias del poder de este período.

\section{MILITARIZACIÓN DE LAS CELEBRACIONES}

Ya en 1702, varias décadas antes de las iniciativas de Amat, la capital chilena había vivido la experiencia de contar con una presencia militar profesional al servicio de las autoridades políticas locales. Ese año, el gobernador Francisco Ibáñez trasladó a Santiago una treintena de soldados de la frontera del sur "para la asistencia y administración de la justicia [...], para que pudiesen asistir y rondar con los ministros, lo cual no se ejecutaba hasta entonces" ${ }^{26}$. Esta tropa, además de estar destinada a controlar la delincuencia urbana, también fue destinada "para la guardia de mi persona", como expresaba el propio gobernador seis años después, al reclamar por la restitución del dinero que, de su propio peculio, había utilizado para pagar a dichos soldados. $\mathrm{La}$ presencia de este destacamento, si bien fue efímera -al cabo del primer año hubo que devolverlos al sur, al no contar con la autorización presupuestaria-, cumplió prontamente con los objetivos que le había fijado la autoridad; esto es, apoyar una conveniente represión -de índole policial- y reforzar con su presencia el despliegue público de la máxima autoridad local.

ría", compuesta por artesanos y otros individuos de grupos modestos nacidos en España: ALLENDESALAZAR, 1962, p. 127.

${ }^{23}$ Ibídem.

${ }^{24}$ Gómez de Vidaurre, 1789, XV, p. 318.

${ }^{25}$ Villalobos, 2000, pp. 278-279; Allendesalazar, 1962, p. 128.

${ }^{26}$ Carta del gobernador al rey. Santiago, 20-VIII-1703. AGI, Chile, 87. 
Esta estrategia venía a calzar con la nueva imagen y papel político que irá asumiendo el gobernador-presidente chileno a lo largo del siglo XVIII, en el marco de una también renovada funcionalidad estético-política del sistema monárquico. No debe parecer extraña, entonces, la significativa coincidencia de este destacamento militar en Santiago con las celebraciones organizadas ese mismo año de 1702 para proclamar al primer rey Borbón de España. Más aún, el propio gobernador apuntaba que, incluso si no hubiese existido el objetivo policial, de todas formas "me hubiera visto precisado a traerlos aquel propio año para la celebridad de la jura de VM"27.

Para la ocasión, de hecho, la autoridad inauguró un segundo evento de proclamación -además de la plaza mayor- en el límite sur de la ciudad, conocido como La Cañada. Una de las consecuencias de esta novedad fue la ampliación de la distancia recorrida por el cortejo, prolongando el tiempo de exposición de los actores del poder ante la admiración pública y, por lo mismo, la exhibición de sus lujosas indumentarias, de su respectiva ubicación jerárquica y de los sonidos marciales que acompasaban el paso con tambores, pífanos y descargas de sus armas. De ahí que la presencia de esta original "guardia presidencial" colaborase en destacar el lugar preeminente ocupado por la autoridad que escoltaban. De ahí también que el gobernador se encargase personalmente de

[...] darles aderezos para los caballos [y] uniformes a mi costa para que me fuesen acompañando en la función de levantar el estandarte en nombre de V. M., debiendo yo por obligación ser el primero que estimulase a todos para la celebridad de un acto de tanta estimación para los vasallos ${ }^{28}$.

Si bien esta participación y la propia presencia del destacamento en Santiago todavía pueden verse como situaciones excepcionales, no cabe duda, por lo visto hasta el momento, que lo vivido ese año constituía una señal auspiciosa de los nuevos aires que pronto empezarían a soplar sobre el universo de prácticas y representaciones políticas de la capital chilena y que se cristalizarían en torno a las exequias de la reina María Bárbara de Portugal, en 1759.

Las ceremonias fúnebres de ese año marcaron una renovada presencia castrense en el espacio ceremonial público, de forma paralela con los cambios y definiciones que hemos visto introducidas por Amat. Tanto en el día de las vísperas como en el de las exequias, en efecto, el cortejo que acompañó al gobernador a la catedral atravesó caminando la plaza mayor, "que estaba guarnecida de las compañías milicianas precedidas de sus oficiales y cabos"29.

Al año siguiente, la proclamación de Carlos III sirvió para el estreno de los Dragones de la Reina en su función de solemnizar las liturgias del poder junto con las

${ }^{27}$ Carta del gobernador Francisco Ibáñez al rey. Santiago, 19-IX-1708. AGI, Chile, 87.

${ }^{28}$ Ibídem.

${ }^{29}$ Testimonio anónimo. Santiago, 20-II-1760. BN. BM. Mss. 191, leg. 4366, ff. 10v-11; Tabla de ceremonias y etiqueta del Cabildo. Santiago, 1760. Archivo Nacional Histórico (en adelante, ANH.), Varios, leg. 217, f. 3. 
compañías de milicias ${ }^{30}$, coincidiendo con el momento en el que el Cabildo recogía la tradición protocolar de la ciudad en una inédita Tabla de ceremonias.... Aquí se estipulaba el espacio oficial que le cabía a los militares en los cortejos políticos más importantes, aquellos que circulaban por las calles para las juras reales y para las misas de los días del rey y de la reina, ubicándolos en el segundo lugar, después de la "nobleza" local. Además, el capitán de Dragones sería el encargado, a nombre de su estamento y de esa misma "nobleza" -"que entran juntos"-, de declamar una de las dos arengas que se pronunciaban ante el gobernador en su palacio -la otra correspondía al provincial de los dominicos, en representación del clero regular- ${ }^{31}$.

La misma tabla ceremonial apuntaba el cambio sustantivo que había experimentado la promulgación pública de los bandos propiamente monárquicos -aquellos que tenían que ver con nacimientos, muertes y ascensos reales-, los cuales ya no sólo estarían escoltados por una comitiva de notables del Cabildo, sino también por un teniente y 24 soldados de la misma Compañía de Dragones. Además, al promulgar el bando en las cuatro esquinas de la plaza mayor, esta tropa debía mostrarse "con espada en mano" 32 .

Las principales fiestas religiosas del calendario litúrgico ligadas a la tradicional vocación militante contrarreformista -como el Corpus Christi- o directamente a la identidad política de la monarquía española -como el apóstol Santiago- también viven un refuerzo en la participación de las milicias locales, en pleno proceso de renovación de sus efectivos y objetivos. En 1764, por ejemplo, se acuartelaron todas las compañías de infantería, incluida la del Comercio, para acompañar al Santísimo durante su recorrido procesional por las calles de la ciudad ${ }^{33}$, mientras que el año anterior habían participado también los cuerpos de caballería en las festividades de la víspera y día de Santiago, "concurriendo previamente los capitanes de ellas y demás oficiales, como también todos los vecinos feudatarios, y demás que deben asistir y acompañar el Real Estandarte"34.

Un análisis destacado merece, por supuesto, atender a la participación que le cupo a lo militar en la apoteósica proclamación de Carlos IV, en 1789. Como lo atestiguan

\footnotetext{
${ }^{30}$ Certificación de la jura de Carlos III. Santiago, 21-IV-1761. ANH, Capitanía General, 690, leg. 21, f. 285.

${ }^{31}$ Tabla de ceremonias y etiqueta del Cabildo. Santiago, 1760. AHN, Varios, leg. 217, f. 5v.

${ }^{32}$ Ibidem, f. 2v; Testimonio anónimo. Santiago, 20-II-1760. BN. BM. Mss. 191, leg. 4366, f. 9.

${ }^{33}$ Bando de 26-V-1764, citado en LEÓN, 1998, p. 53.

${ }^{34}$ Bando de 30-VI-1763, citado en Ibídem, pp. 53-54. En 1778 se emitió una real orden sobre honores militares debidos al Santísimo Sacramento, reforzando disposiciones de 1729 frente al conflicto suscitado entre las autoridades eclesiásticas y militares en una procesión del Corpus en la Coruña. El monarca señalaba que "cuantos honores, humildes rendimientos y actos de veneración puedan dedicar los mortales a Dios sacramentado son insuficientes y cortos respecto de lo que corresponde a tan soberano objeto [...] resolviendo por punto general para todos sus dominios de españa y de las Indias [...] que cuando la tropa está formada o deba formarse con banderas, y pase pública y procesionalmente entre filas, o aún frente al Santísimo Sacramento de la Eucaristía, se avancen y rindan las banderas, tendiendo sus tafetanes para que, situados sobre ellas los sacerdotes o preste que conduzca la custodia, heche éste la bendición a las armas". La orden llegó a Santiago en junio del mismo año y de inmediato el gobernador Agustín de Jáuregui la respondió, señalando que había impartido los avisos correspondientes a los prelados eclesiasticos y a todos los jefes militares de su jurisdicción. Carta de Agustín de Jáuregui al ministro de Indias. Santiago, 2-VI-1778. ANH, Morla Vicuña, 6, leg. 167, ff. 374v-375v.
} 
los diversos informes enviados desde muchas ciudades hispanoamericanas, se trató de una fiesta inédita en sus proporciones y despliegue escénico, no sólo para Chile sino también para el resto del continente ${ }^{35}$. Por ello no debe extrañar que encontremos a la compañía de Dragones y al conjunto de milicias urbanas en el espacio protagónico que en el sistema colonial le estaba asignando al universo castrense. De hecho, la primera, precedida por clarines y tambores, encabezaba la cabalgata oficial que ese día recorrió el trayecto entre la plaza mayor y el segundo tablado levantado en La Cañada. Le seguían los maceros del Cabildo y, a continuación, los jefes y oficiales de todos los cuerpos militares de la capital y de los partidos inmediatos, con espada en mano. Luego venía el resto de notables "no militarizados" de la ciudad, en una relación de continuidad donde "nada separaba este cuerpo de militares del de caballeros vecinos que le seguían, pues ambos iban a continuación y bajo de las mazas de Cabildo"36. Cerraban el cortejo las autoridades y las corporaciones civiles, y los caciques mapuches que fueron invitados y viajaron especialmente desde la Araucanía para la ocasión ${ }^{37}$. Los flamantes cuerpos de milicias, por su parte, que para esta época ya habían consolidado su reorganización formal y su posicionamiento en el seno de los actores urbanos, se formaron a lo largo del trayecto en dos filas, en medio de las cuales circuló el desfile ${ }^{38}$. No debe haber faltado en este despliegue sociocromático el batallón de pardos que, según un contemporáneo, a sólo dos años de la reestructuración que hemos visto más arriba "se distinguen mucho, así en el ejercicio que hacen como en lo bien traído del uniforme, que sólo se ponen cuando van a alguna función en cuerpo de milicia" 39 .

Otro aspecto a destacar fue la presencia del espíritu castrense en el desfile de los carros de los gremios. El de los carpinteros, por ejemplo, era precedido por una persona vestida de militar y un piquete de 20 hombres uniformados, "con sus tambores". El de los abasteros, que lo precedía, también iba encabezado por un "embajador" y otros 20 hombres "con fusiles y atambores [sic], que llevarán una muy lucida marcha”. El carro que hicieron conjuntamente los gremios de broncería, herraduría [sic], hojalatería y cantería iba acompañado por 12 soldados a sus costados, lo mismo que el preparado por los silleros, albañiles y sombrereros, y el que fabricó el gremio de los carroceros. El carro de los barberos contemplaba un acompañamiento de cuatro docenas de soldados, más un segundo contingente de 24 soldados, un tambor y pífano. Por último, en el carro confeccionado por los herreros, petaqueros y curtidores participaban 17 soldados "con sus fusiles" y dos tambores ${ }^{40}$.

${ }^{35}$ Hemos tratado en profundidad esta proclamación y su contexto en Valenzuela Márquez, 2005.

${ }^{36}$ Medina, 1963, III, p. 132.

${ }^{37}$ Relación de las funciones hechas por la muy noble y leal ciudad de Santiago capital del Reyno de Chile, y su governador y capitán general brigadier don Ambrosio [O']Higgins Vallenar en la proclamación que practicó por nuestro soberano el señor don Carlos Cuarto (Dios le guarde), rey de España, y de las Indias. ANH, Morla Vicuña, 6, ff. 429v-453v. El informe oficial que se envió al Consejo de Indias se encuentra en AGI, Indiferente General, 1608, s/f.

${ }^{38}$ Pérez García, ca. 1810, XXIII, p. 423.

${ }^{39}$ GómeZ de Vidaurre, 1789, XV, p. 318.

${ }^{40}$ Expediente sobre las fiestas reales. Santiago, 1789. ANH, Capitanía General, 823, leg. 15921, ff. 36-51. 
Los ejemplos sobre expansión de la presencia y la actividad militar en las fiestas públicas se acumulan durante la segunda mitad del siglo y podríamos extendernos en largas enumeraciones y detalles que sólo vendrían a confirmar lo que hemos estando esbozando. Quisiéramos más bien concentrarnos en la actitud asumida por la institución que más reticencias demostró ante el avance de lo militar: la Real Audiencia. En efecto, incluso la institución más conservadora se dejó tentar por los nuevos aires marciales, puesto que al año siguiente de la jura de Carlos IV pretendía que "cuando entra o sale en cuerpo en el palacio del presidente a sacarlo para asistir a funciones de tabla o dejarlo de regreso, le haga la guardia de éste los honores de capitán general de provincia" ${ }^{41}$. Sin embargo, el gobernador Ambrosio O'Higgins -sujeto paradigmático de su época, pues la evolución de su carrera contempló una primera fase en tareas de ingeniería y, luego, en distintos escalafones de las milicias disciplinadas chilenasreclamó que esta pretensión era opuesta a lo señalado por las Ordenanzas Generales de los Reales Ejércitos, donde se estipulaba que la guardia de los gobernadores o comandantes de plaza sólo debía rendir honores a las personas de grado superior, "verificándose lo mismo en cuanto al reverendo obispo en las ocasiones que vaya a visitar al presidente por lo respectivo a los honores de mariscal de campo, que por ordenanza le corresponden" 42 .

De la cita anterior, entonces, se colige que los saludos castrenses también habían alcanzado el protocolo referido a la principal autoridad eclesiástica, lo que se verá refrendado por el Consejo de Indias en 1793, cuando determinó "Que también es justo que al obispo se le guarden los honores de mariscal de campo conforme al artículo $7^{\circ}$, título $4^{\circ}$, tratado $3^{\circ}$ de las reales ordenanzas militares, como se ejecuta en España por decoro de su alta dignidad"43.

Hay que hacer notar, en todo caso, que la Audiencia no vivía ajena al protocolo militar, pues ya recibía honores por parte de las demás tropas y guardias, por lo que esta nueva pretensión se refería sólo a la guardia del gobernador -en tanto capitán general-. O'Higgins aprovechó la oportunidad para recalcar que los saludos que recibía de su guardia no podían ser extensibles a ninguna otra autoridad, ya que correspondían a los de un general de ejército "en campaña", recurriendo a un paradojal arcaísmo al recordar disposiciones del siglo XVII "sobre que debe reputarse el servicio militar de Chile por de guerra viva semejante a la de Flandes"

No obstante, el Consejo de Indias finalmente confirmó los deseos de la Audiencia, considerando necesario que se le hicieran los honores indicados

[...] en cualquier acto, tiempo o lugar en que vaya en cuerpo de tal y por consiguiente cuando entre y salga en la casa del presidente, pues estos distintivos son muy propios

${ }^{41}$ Carta del gobernador Ambrosio O’Higgins al rey. Santiago, 7-V-1790. ANH, Morla Vicuña, 39, leg. 15, f. 107. El tribunal se basaba para ello en cédulas reales de 1786 y 1788.

${ }^{42}$ Ibidem, f. 107v. John Lynch ha mostrado como los actos protocolares se vieron afectados por las reformas borbónicas, sobre todo en el caso de los obispos en relación a los intendentes, quienes antes se hallaban al nivel del virrey en los actos protocolares: LYNCH, 1981.

${ }^{43}$ Carta del gobernador Ambrosio O’Higgins al rey. Santiago, 7-V-1790. ANH, Morla Vicuña, 39, leg. 15 , ff. $109 \mathrm{v}-110$.

${ }^{44}$ Ibidem, ff. $107 \mathrm{v}-108$. 
y necesarios en aquellos dominios para que sus habitantes conozcan más a lo vivo la soberana autoridad de V. M., respeto y veneración que están obligados a prestarle"45.

La Real Audiencia terminaba así por ser cooptada dentro del universo castrense imperante, ratificando con ello el rol alcanzado a fines del siglo por el estamento militar como fuente de legitimación, como referente de autoridad y como canal omnipresente de las prácticas políticas de la época, tanto en el plano administrativo como, en este caso, simbólico.

\section{SONORIDAD CASTRENSE Y CAMPANAS ECLESIÁSTICAS}

Al estudiar los usos y las capacidades persuasivas de las ceremonias públicas aparece en un lugar predominante, junto al despliegue visual, la articulación de ruidos que están asociados al poder y que ayudan a marcar la espectacularidad y la solemnidad del evento. Ya hemos señalado en otro trabajo el papel jugado por las campanas eclesiásticas y el lenguaje convencional que transmitía, a través de códigos acústicos descifrables por los habitantes, desde las horas del día hasta las emergencias locales ${ }^{46}$. Los repiques generalizados y unísonos de los templos urbanos anunciaban también el nacimiento de un príncipe o la llegada de un nuevo gobernador, participando plenamente del despliegue sensitivo que pretendía revestir al evento con la carga legitimadora y persuasiva que orientaba su ejecución.

El siglo XVIII continuará y reforzará esta participación, sobre todo en el contexto regalista que irá ampliando progresivamente el control de la monarquía sobre la Iglesia colonial. El año 1794 marca, en este sentido, un hito importante con respecto al papel ocupado por los repiques en las ceremonias del poder, pues se dictó un reglamento para regular los toques sonoros de las campanas en los dominios americanos. En pleno racionalismo borbónico, en que se aplicaban reformas al comercio, a las costumbres o al ejercicio de la autoridad, se buscaba reforzar el control monárquico y se intentaba desmontar la parafernalia barroca que rodeaba a las exteriorizaciones del culto religioso -expresiones que el clero ilustrado ahora calificaba como "excesos indecentes"-, no deja de ser significativa una restructuración general por parte del poder civil del lenguaje masivo de las campanas. En síntesis, lo que esta medida hizo fue diferenciar claramente la magnitud jerárquica de los repiques otorgados al poder civil y al clerical con respecto al resto de los habitantes. Para ello, disminuyó al mínimo el número de tañidos que se debían dar por algún acontecimiento cotidiano y privado, reelaborando, en su cantidad y frecuencia, aquellos que se debían dar por los avatares del imperio y de sus autoridades metropolitanas y locales.

Así, por ejemplo, sonaría un repique general con todas las campanas y durante 15 minutos "en cualquier hora del día o de la noche en que llegue correo de España con la gustosa e importante noticia de la salud de nuestros Augustos Soberanos y su Real

\footnotetext{
${ }^{45}$ Sesión del Consejo de Indias. Madrid, 29-VII-1793. ANH, Morla Vicuña, 39, leg. 15, ff. 109v-110.

${ }^{46}$ Valenzuela Márquez, 1992.
} 
familia para que no se retarde este consuelo a su fiel y amante pueblo" ${ }^{\text {47 }}$. Lo mismo sucedería cuando se conociera la muerte de un rey y el ascenso de su sucesor o algún acontecimiento vital que signase trascendentalmente la vida pública de la casa real, en cuyo caso se debían dar de inmediato 200 campanadas. En caso de fallecimiento, por su parte, se continuaría doblando por un día completo ${ }^{48}$.

Una jerarquía distinta en número y frecuencia, aunque igualmente aparatosa, se daba para los eventos relacionados con las autoridades locales, desde los gobernadores y obispos hasta los miembros del Cabildo secular y canónigos del eclesiástico. Cada cargo tenía asignado una cantidad precisa de campanadas, ya fuese para el ascenso del ocupante, sus enfermedades, su agonía o su fallecimiento ${ }^{49}$.

No obstante estos refuerzos y sistematizaciones, lo que aparece con inusitada fuerza en el panorama sonoro del Santiago dieciochesco son los ruidos militares. Por cierto, la sonoridad marcial no había estado ausente en la centuria anterior, cuyas liturgias contaban generalmente con descargas de fusilería y con instrumentos musicales de guerra, sonidos que se conjugaban con las campanas, tanto en celebraciones civiles como eclesiásticas ${ }^{50}$. Pero lo nuevo para la época que estudiamos será la introducción de la artillería, completamente ausente en el siglo XVII, donde sólo podía recurrirse a las salvas de arcabuces de las milicias de infantería. A diferencia de estas últimas, las descargas de cañones van a permitir a los actores del poder contar con un instrumento de mayor alcance sonoro, con una estridencia que podía conjugar de mejor forma el temor disuasivo ante el poder -virtualmente- represivo del Estado y la espectacularidad emotiva y apoteósica necesaria para las renovadas celebraciones que el sistema desplegó localmente en la segunda mitad del siglo.

En este sentido, al menos durante los años que siguieron a las reformas de Amat, más que una pugna por ocupar el espacio político-auditivo de los santiaguinos quizás podríamos hablar de una complementación entre los sonidos eclesiásticos y los castrenses. De hecho, durante las exequias por la reina María Bárbara de Portugal, en 1759, si bien hubo despliegue de las compañías milicianas de la ciudad, los ruidos que se escucharon fueron exclusivamente los de las campanas eclesiásticas, tanto para el anuncio como para los cortejos de la víspera y del día de las honras fúnebres ${ }^{51}$. Respecto de los funerales reales, la Tabla de ceremonias..., elaborada por el Cabildo en 1760, estipulaba claramente los tiempos asignados a cada uno de los sonidos institucionales. Así, tanto en el día en el que las autoridades y notables iban a dar los pésames al gobernador como en el de las vísperas de las honras fúnebres, se repicaban dobles de 100 campanadas pausadas en la catedral "y siguiendo a éstos la artillería, que continúa hasta el día siguiente" ${ }^{52}$.

\footnotetext{
${ }^{47}$ Reglamento sobre uso y toque de campanas, originado en La Habana y extendido al resto de las Indias por el artículo 5 de una Real Cédula. Madrid, 1-III-1794. ANH, Capitanía General, 708, f. 150v.

${ }_{48}$ Ibídem, arts. 15,18 y 19, ff. $153 \mathrm{v}-154 \mathrm{v}$. Un tiempo de repique similar se disponía para la muerte del Papa y la elección de su sucesor, en lo que podemos calificar como el signo de un intento de equiparar simbólicamente ambas figuras y cabezas de sendos poderes.

${ }^{49}$ Ibídem, arts. 11 y $20-23$, ff. $152 \mathrm{v}, 154 \mathrm{v}$ y $155 \mathrm{v}$.

${ }^{50}$ Valenzuela Márquez, 2001, pp. 363-374.

${ }^{51}$ Informe del gobernador Manuel de Amat. Santiago, 20-II-1760. BN. BM. Mss. 191, leg. 4366.

${ }^{52}$ Tabla de ceremonias y etiqueta del Cabildo. Santiago, 1760). AHN, Varios, leg. 217, f. 3.
} 
Un año después se celebraban las exequias por la reina María Amalia de Sajonia -esposa de Carlos III-. Desde el mediodía hubo doble general de las campanas, con lo que "se anunció a las demás de los conventos de religiosos y religiosas que siguiesen con puntualidad". En este caso, sin embargo, el repique fue acompañado simultáneamente -y, sin duda, ahogado- por el "estruendo general de la artillería que se disparó en el cerro de Santa Lucía, en que la nueva compañía de artilleros tenía dispuesta cierta especie de batería". Por la tarde se celebraron las vísperas, con asistencia de todas las autoridades, cuyo ingreso al templo fue marcado con una descarga de fusiles y una salva de artillería que "ayudaban a solemnizar función tan seria". Los cañones continuaron disparando toda la noche, cada media hora, hasta la mañana siguiente en que se realizaron las exequias, cerrando la función una descarga general de fusilería y de artillería ${ }^{53}$.

No sólo se inauguraba así la incorporación sistemática del ruido de cañones en las ceremonias públicas, en medio de las reformas que Amat había introducido recientemente en la composición y la presencia castrense en la capital, sino que también se percibía una tendencia a ir más allá de la mencionada complementariedad sonora eclesiástico-militar. A partir de ahora, la flamante compañía de artilleros mulatos, "de que se hecha mano en todos los casos, que se usa en ella en las funciones públicas" $"$, será convocada regularmente para estos eventos y la cima del cerro Santa Lucía de la ciudad se convertirá en el lugar apropiado para proyectar sobre toda la ciudad el estruendo de los cañones.

Dominando desde la altura a los campanarios eclesiásticos, los sonidos militares tenderán a superponerse a las campanas, virtualmente subordinadas, en lo que podría considerarse un correlato simbólico de lo que estaba ocurriendo entre la Corona y la Iglesia. De hecho, las salvas de artillería se van a especializar en marcar sonoramente los hitos principales de las ceremonias que ocurrían en el interior de la catedral, comunicándolas a los súbditos-fieles apostados al exterior y reemplazando en esto a las propias campanas.

En 1760 los artilleros pardos pudieron estrenar su papel en la proclamación del rey Carlos III. Los sonidos militares coparon los momentos posteriores a la proclamación oficial, primero con los instrumentos musicales (cajas, clarines, timbales, trompetas, etc.); más tarde, y paralelamente al tradicional repique general orquestado por las iglesias de la ciudad, comenzó el retumbar de la artillería, con una triple descarga disparada por los 24 cañones que se habían emplazado en el cerro, a los que se unieron las salvas disparadas por la fusilería de los infantes. Por cierto, cada ceremonia ejecutada a lo largo de esos días -civil o religiosa- iba acompañada por descargas de ambos cuerpos. También se confirmó el papel asignado a los disparos para marcar los principales ritos de la liturgia religiosa, pues durante la respectiva misa de acción de gracias se repitieron las salvas de la artillería y de la infantería al momento de la consagración ${ }^{55}$.

\footnotetext{
${ }^{53}$ Relación anónima. Santiago, 14-III-1761. En Medina, 1952, pp. 83-84.

${ }^{54}$ Santa Cruz, Juan José de. "Noticia de Santiago". Santiago, 8-IV-1790. Reproducida en Sagredo Baeza - GonzÁlez Leiva, 2004, p. 482.

${ }_{55}$ Certificación de la jura de Carlos III. Santiago, 21-IV-1761. ANH, Capitanía General, 690, leg. 21, ff. 281-287.
} 
Los años siguientes irán consolidando esta presencia. Así, por ejemplo, la noche que falleció el gobernador Guill y Gonzaga, en agosto de 1768, comenzaron de inmediato las salvas de artillería que duraron hasta el funeral que se celebró el día siguiente, disparándose con intervalos de 15 minutos "que acompañó los dobles parte de aquella hora desde su muerte y rogativas en todos los conventos desde que se agravó su mal". Durante el entierro se agregaron también los disparos de la compañía de Dragones, que se produjeron al salir de la iglesia, al entrar, al alzar y al sepultarlo ${ }^{56}$.

En 1789, por su parte, entre los preparativos dispuestos por el gobernador O'Higgins para celebrar las exequias por Carlos III se determinó que "desde la diana" y por tres días consecutivos se comunicase el suceso a la población a través de tres tiros de cañón y repiques de las campanas de la catedral y de las iglesias de la ciudad. Luego vino la proclamación del sucesor donde, con toda la artillería dispuesta en el cerro, se estuvo disparando a lo largo de todo el trayecto del cortejo principal ${ }^{57}$.

\section{LA INDEPENDENCIA CONSOLIDA LA HEGEMONÍA}

El tránsito de la monarquía a la república, por el hecho de haberse realizado en medio de encarnizadas guerras, puede verse también como una consolidación de la tendencia hegemónica que el universo de lo militar estaba proyectando sobre la mayoría de las articulaciones políticas locales. Más allá de los espacios simbólicos y de las representaciones sociales sobre el papel de lo castrense en el prestigio individual o en las liturgias públicas, el despliegue de uniformes, de armas y de sangre cristalizó un modelo de vida, de valores y de presencia pública que se mantendría por largas décadas en la historia de éste y de otros países del continente.

De hecho, como apunta Archer, el estallido de las guerras de la Independencia significó que la posición de los militares se alterara radicalmente; su influencia se expandió en forma consustancial a la naturaleza de los conflictos que revolucionaban a las colonias, y su papel en la vida social y política se acrecentó notoriamente. Los concejos municipales y los funcionarios locales perdieron su patronazgo sobre las designaciones y promociones de los oficiales, el ejército dejó de tener en cuenta a los administradores civiles y de respetar sus jurisdicciones y privilegios. Los oficiales regulares, por su parte, encontraron que las guerras les brindaban muchas oportunidades para sus pretensiones de movilidad y de $\operatorname{poder}^{58}$.

Podríamos situar el primer despertar local a la realidad de la guerra en 1806, cuando la invasión inglesa al puerto de Buenos Aires motivó que las milicias de Santiago se reunieran diariamente para recibir instrucción militar. El temor a que el conflicto se extendiera a Chile hizo que al año siguiente se estableciera el campamento de Las Lomas, al norte de la capital, donde los milicianos se concentraban durante un mes

${ }^{56}$ De Los Ríos, 1913, pp. 53-55.

${ }^{57}$ Medina, 1963, III, p. 133; Expediente sobre las fiestas reales. ANH, Capitanía General, 823, leg. 15921, f. 53; Pérez García, ca. 1810, II, p. 423.

${ }^{58}$ Archer, 1993, pp. 250-252. 
en estos ejercicios ${ }^{59}$. La población de Santiago comenzó entonces a vivir de manera intensa y sistemática al ritmo de la estética castrense, como señalaba un testimonio de esos años ${ }^{60}$.

El año 1810, por su parte, marca un nuevo y definitivo repunte de este proceso, por el carácter y las circunstancias que rodearon el establecimiento de la Junta de Gobierno, el 18 de septiembre de ese año, como recogía en su diario el ingeniero militar Manuel Olaguer Feliú, que en ese momento cumplía un importante papel en el mando de la capital ${ }^{61}$. El día 19, por su parte, se publicaba el acta de instalación de la Junta, llevada a cabo "con una ostentación y aspecto majestuoso" que, a juicio del sacerdote monarquista Melchor Martínez, intentaba "infundir en el pueblo y en los leales vasallos el terror y el espantoso carácter del nuevo sistema" ${ }^{2}$. De hecho, la élite capitular que organizó la ceremonia se esmeró en rodearla con un aparato espectacular que pudiera dar lustre y prestigio a las nuevas autoridades. Para ello se organizó una vistosa columna de cerca de 1.000 hombres armados que recorrió las principales calles de la ciudad al son de tambores y pífanos ${ }^{63}$.

$\mathrm{Al}$ día siguiente, en lo que constituía una clara muestra de continuidad con las formas tradicionales de legitimación festiva, el Cabildo preparó una ceremonia en la plaza de armas para que los distintos actores declararan públicamente su fidelidad y respeto a la nueva Junta. Así, en forma similar a las proclamaciones reales, un tablado sirvió de escenario para que se ubicaran los vocales y recibieran el juramento respectivo. Resulta interesante constatar que en la ejecución de este rito la élite capitular puso cuidado en incorporar a toda la oficialidad de las tropas, los regimientos del Príncipe, de la Princesa y el de infantería del Rey, y las milicias que habían sido convocadas para solemnizar el acto. Todos ellos prestaron juramento de obediencia -al rey y a la Junta- a continuación del clero, demostrando el papel central que les correspondía, al lado de Dios, en sostener y legitimar a la nueva autoridad. De hecho, al nuevo presidente Toro se le hicieron honores de capitán general. Al cabo de esta ceremonia se dejaron sentir los cañones, con la ya tradicional costumbre de cerrar los eventos festivos del poder con tres salvas de artillería de 21 disparos cada una ${ }^{64}$.

En los meses posteriores terminó por consolidarse la participación permanente de los soldados y de sus ruidos en los espacios y los momentos destinados a las celebraciones del poder. Los años que siguen serán de una temporalidad más acelerada e inmediatista, con cambios bruscos, sucesos impredecibles y volteretas políticas inimaginables algunas décadas atrás. Así también se hicieron más numerosas y espectaculares las ocasiones festivas, mientras que la omnipresencia litúrgica de lo militar responderá a la coyuntura, cristalizando la invención de lo que serán las tradiciones republicanas. Basta un simple recorrido por la lista de estos eventos para dar cuenta de la regularidad con que, por ejemplo, las tropas regulares y las milicias de la ciudad

\footnotetext{
${ }^{59}$ Barros Arana, 1999-2005, VII, p. 220.

${ }^{60}$ Carta de Manuel de Salas. Santiago, s/d. Citada en Meza Villalobos, 1957, p. 22.

${ }^{61}$ Olaguer Feliú, 1989, p. 29; Barros Arana, 1999-2005, VIII, p. 216.

${ }^{62}$ Martínez, 1815, I, p. 118.

${ }^{63}$ Ibídem; Olaguer Feliú, 1989, p. 34.

${ }^{64}$ Martínez, 1815, I, p. 120; Barros Arana, 1999-2005, VIII, pp. 226-227.
} 
aparecen formadas en la plaza mayor para misas de agradecimiento o de aniversario en la catedral, así como las infaltables descargas de artillería y de fusilería al principio, en medio y al final de la ceremonia ${ }^{65}$.

Incluso, la refrendación de actos e instituciones eminentemente civiles, como el nuevo Congreso que se inauguró en 1811, conllevó despliegues similares, en una clara señal de que la emancipación era aún un proyecto, de que ese proyecto estaba en pleno debate en medio de las ambigüedades monarquistas aún vigentes y de que, finalmente, sólo podría sostenerse en las armas y en las charreteras, como una inevitable experiencia colectiva. Ello quedó en evidencia durante el reconocimiento público de los diputados electos -recibidos en la catedral con una estruendosa salva de artillería y frente a la tropa formada en la plaza mayor- y, sobre todo, durante la ceremonia de apertura de sus sesiones ${ }^{66}$.

La tendencia quedó sellada a fines de ese mismo año, cuando José Miguel Carrera decidió acelerar el proceso de quiebre, aboliendo el efímero Congreso y reivindicando la hegemonía de lo militar en los aparatos de decisión que correspondían a una revolución. Como señala Claudio Rolle, Carrera sería el gran impulsor de la intromisión del mundo militar en la gerencia política del país, instaurando un verdadero "régimen pretoriano", que no estuvo exento de oposiciones radicalizadas por parte de las élites civiles. Carrera se apoyó casi exclusivamente en el aparato militar para gobernar y para definir una línea decididamente emancipadora, tarea en la que fue ayudado, paradojalmente, por las propias autoridades españolas del Perú, cuyo envío de tropas a Chile potenció un sentimiento colectivo local y la posibilidad para el gobierno de reivindicar una legitimidad basada en la defensa de la Patria. Los militares, entonces, "pasaron a desempeñar el papel de defensores de la libertad y agentes de la revolución"

En efecto, vemos que durante esos años el ejército se vio comprometido en una serie de acciones que no guardaban relación con la defensa del territorio, sino más bien con la conquista y conservación del poder, dentro del proyecto republicano. La reorganización y ampliación de los distintos regimientos, especialmente en el distrito santiaguino, estuvieron también inspiradas en los principios cívico-militares de la revolución francesa y la homologación que esta última proponía entre los conceptos de "ciudadano" y "soldado"68. De esta forma, además de contar con la incorporación voluntaria de patriotas entusiastas ${ }^{69}$, las autoridades dictaminaron el servicio militar obligatorio con el fin de proyectar colectivamente tanto la necesidad de cohesión y defensa ante amenazas "externas", como el sentimiento de que lo castrense era parte

${ }^{65}$ Por ejemplo, la misa que se celebró el 11 de octubre de 1810, con el objetivo de dar gracias a la divinidad por el establecimiento de la Junta: Martínez, 1815, I, p. 139.

${ }^{66}$ Ibidem, I, pp. 236, 244 y 250.

${ }^{67}$ Rolle, 1990, p. 294.

${ }^{68}$ Cfr. Martínez, 1815, I, pp. 185-187; Allendesalazar, 1962, p. 128. En 1812, por su parte, Carrera creaba el regimiento de caballería Húsares de la Gran Guardia.

${ }^{69}$ Cfr., por ejemplo, la creación en octubre de 1811 del "Batallón de Patriotas Voluntarios de Santiago", quizás el mismo que se crea definitiva y oficialmente en diciembre de ese año, bajo el nombre de "Regimiento Primero de Milicias Disciplinadas de Infantería Ligera de Voluntarios de la Patria". Decreto de gobierno. Santiago, 12-XII-1811. Archivo O’Higgins, "Primer apéndice”, pp. 59-61. 
de la nueva ciudadanía. Esta actitud puede ser interpretada, en parte, como un rescate del espíritu tardocolonial de las antiguas milicias, pero, en realidad, estamos frente a una postura más original a nivel local, claramente napoleónica en sus orígenes, que iba mucho más allá de la "militarización simbólica" precedente y que, por lo tanto, no debe asumirse automáticamente como una simple continuidad de la era borbónica ${ }^{70}$.

Dicho reclutamiento, por su parte, se reforzará en medio de las urgencias derivadas del avance restaurador de las tropas enviadas desde el Perú. De esta manera, en 1813 la guerra motivó al gobierno a redoblar los esfuerzos para el enrolamiento, obligando a "que todos los individuos existentes en el territorio de Chile se alistasen y reconociesen cuerpos militares, a fin de estar prontos cuando les llamen las autoridades" $"$.

Por cierto, hay que considerar el eventual fracaso de esta iniciativa, al menos en lo que se refiere a su trasfondo ideológico, observable en la indiferencia o clara reticencia de los sectores populares a combatir en la guerra ${ }^{72}$. No obstante, como apunta Leonardo León, para los miembros de estos grupos ser "soldado de la Patria" significaba "dejar atrás el anonimato". Por ello, el apego a las nuevas instituciones y a su proyecto de país se habría canalizado, más que en los discursos racionales de proclamas y bandos, en el aparato simbólico de banderas, uniformes y emblemas que las nuevas autoridades desplegaron por doquier y que intentaban generar un sentimiento de identidad entre los reclutas, sus respectivos regimientos y la institucionalidad emergente ${ }^{73}$.

Retomando nuestra línea de argumentación, vemos que el gesto de abolición del Congreso que marcó el quiebre en 1811 no pudo ser más representativo de la nueva realidad, pues se dispusieron numerosas tropas en la plaza y una serie de cañones apuntando a la sala del Congreso ${ }^{74}$. El líder de la acción, José Miguel Carrera, señalaba entonces una senda claramente rupturista, al encabezar un golpe de estado contra las instituciones meridianamente continuistas de la coyuntura iniciada en 1810. No obstante, en septiembre de 1812 se esmeró para celebrar el aniversario de la primera Junta con actos religiosos tradicionales como un Te Deum en la catedral, con elementos de novedosa autonomía, como disponer un nuevo emblema de gobierno -una bandera tricolor- en un edificio tan representativo de la impronta borbónica, como era el palacio de La Moneda, y, por último, con aquellos sonidos y uniformes cuya presencia reforzada ya formaba parte incuestionable y necesaria de este tipo de eventos ${ }^{75}$.

Lo militar seguirá potenciándose de la mano con la coyuntura bélica que se abría luego de la llegada de las tropas restauradoras enviadas desde el Perú. Ya hemos visto las disposiciones de reclutamiento obligatorio y generalizado. El gobierno se transformó en una instancia en campaña, que a veces estaba en la capital y otras siguiendo las movilizaciones y batallas, cuyas vigilias y desenlaces eran comunicados y "vivi-

\footnotetext{
${ }^{70}$ Rolle, 1990, p. 297.

${ }^{71}$ Decreto de la Junta de Gobierno. Santiago, 6-V-1813. En Boletín de leyes i decretos del gobierno (1810-1814), pp. 219-220.

72 LEÓN, 2002.

${ }^{73}$ Ibidem, pp. 260-261.

${ }^{74}$ Martínez, 1815, II, p. 40.

${ }^{75}$ En la mañana del aniversario, a la hora de la diana, se hizo una salva de 31 cañonazos y se fijó la bandera tricolor en La Moneda. Luego de la misa de acción de gracias hubo Te Deum y salva de 21 cañonazos, la que se volvió a repetir al ponerse el sol: TALAVERA, 1937, pp. 645-651.
} 
dos" por la población santiaguina entre rogativas, campanas eclesiásticas, descargas de artillería y las nuevas sonoridades festivas aportadas por las bandas musicales ${ }^{76}$.

Lo cierto es que, pocos meses después, el triunfo de la restauración monárquica traerá la necesidad de resignificar el aparato ritual cívico-eclesiástico-militar en función de los nuevos requerimientos políticos, si bien el contexto bélico también marcaba el origen de las flamantes autoridades y seguiría alimentando la dinámica gubernativa en los años siguientes, al calor de la latente rebelión patriota que permanecía activa allende los Andes. El ambiente castrense siguió imperando tanto en el plano de la vida social como en el de las celebraciones del poder.

En el ámbito de las celebraciones, vemos cómo la refundación del tribunal de la Real Audiencia, llevada a cabo en marzo de 1815, se verificó en medio del despliegue de las tropas de guarnición y milicias locales, rodeando el entarimado que se dispuso en medio de la plaza mayor ${ }^{77}$. Allí el victorioso monarquista Mariano Osorio aprovechó también para reproducir la tradicional ceremonia de toma de posesión de su cargo de gobernador y la élite capitular tuvo la posibilidad de intentar eludir su reciente aventura autonomista -o, en el caso de sus miembros monarquistas, reactivar su posición ideológica- haciendo entrega de las llaves de la ciudad. La insignia que primó, en todo caso, fue "la del mando militar, con la entrega de un bastón que transfiere el antecesor, subrogando ahora esta ritualidad del oidor decano". Las tropas se mantuvieron en la plaza hasta después de que la autoridad hubo prestado el juramento privado como presidente en la sala de la Audiencia, haciéndole los saludos de rigor y las descargas correspondientes mientras caminaba con su comitiva y edecanes hacia su palacio, "mandando su señoría hacer fuego empezó la fusilería y artillería alternando una lucida salva que con el general repique de campanas, y sonido de muchos voladores de fuego artificial exitaban el júbilo, y entusiasmo que inundaba a todos los vecinos de Santiago"78.

Las nuevas autoridades reencontraban en la parafernalia festiva el espacio que necesitaban para intentar tejer una nueva red persuasiva de apoyo a la restauración, y para ello contaban con la ayuda inestimable de los dispositivos sonoros y visuales, indudablemente espectaculares, que brindaba el mundo castrense. Por todo ello no se dudó en desplegar incesantes celebraciones, que colmaron el calendario público de esos meses decisivos en los que la monarquía buscaba reinstalarse en este lejano rincón del falleciente imperio. Sin ir más lejos, a los pocos días del evento anterior se ordenaba celebrar en Santiago y en el resto de las villas chilenas el aniversario de la entrada de Fernando VII en territorio español, después de su cautiverio en Francia. El gobernador dispuso que la noche previa se iluminase la ciudad "y que el alegre repique general de las campanas avisase al público cuan festiva debe serle eternamente la memoria de este faustísimo suceso". Al amanecer se hizo una salva real de artillería en la plaza, la que se repitió a la hora del Te Deum y al ponerse el sol. Los numerosos brindis que acompañaron el festín que luego se dio en el palacio de gobierno fueron

\footnotetext{
${ }^{76}$ ZaPiOLA, 1974, P. 20.

77 Oficio del gobernador Mariano Osorio al virrey. Santiago, 16-III-1815. En AA.VV., 1950, XXXV, pp. 126-127.

${ }^{78}$ Ibídem.
} 
concluidos con otra salva de 21 cañonazos, conforme a la tradición que asignaba a dichos sonidos la tarea de anunciar al espacio colectivo los momentos más importantes de los ritos privados del poder ${ }^{79}$.

El 30 de mayo, por su parte, siendo el día de San Fernando, se festejó al monarca desde el amanecer, también con una salva de 21 cañonazos. Las tropas se formaron en los cuatro ángulos de la plaza esperando la celebración del tradicional Te Deum en la catedral. Entre la alegría de los monarquistas y las estrategias acomodaticias de las corporaciones -como el Cabildo secular, que asistió en pleno, así como el "noble vecindario"-, vemos cómo se congregan en este evento las instituciones tradicionales -como la recientemente restaurada Real Audiencia-, al alero de las armas, en la liturgia legitimadora de la Iglesia y al son de las ya tradicionales salvas de cañones que se repitieron al comenzar la misa, al elevar la hostia consagrada y al concluir la liturgia. También se restauraron ritos de vieja raigambre colonial como el besamanos al vicario de la monarquía en su palacio, llevado a cabo por parte del oidor decano -en nombre de la Audiencia-, del rector de la Universidad y del prelado de Santo Domingo -en representación de las órdenes religiosas ${ }^{80}$.

El regreso de los patriotas al poder, luego del triunfo de Chacabuco y el ascenso de su líder Bernardo O'Higgins, trajo aparejado un nuevo y decisivo refuerzo de la hegemonía de lo militar dentro del aparato de gobierno y en la construcción del nuevo estado republicano. Ello se tradujo, por extensión lógica, en la presencia de uniformes, pólvora y sonidos marciales en el espacio público y, en particular, en los despliegues celebrativos que ahora se reorientaban hacia la legitimación y la memoria de los vencedores. Así, por ejemplo, y a diferencia de Osorio o Marcó, que durante la restauración sólo se hicieron acompañar por uno o dos soldados, con O'Higgins se hace presente una escolta "numerosa y lujosamente montada y vestida", y omnipresente en los desplazamientos públicos del director supremo ${ }^{81}$.

El orden protocolar fue de inmediato adecuado a las nuevas circunstancias y a la primacía de los actores emergentes, y el nuevo mando militar rápidamente recogió la importancia que debía tener -y que siempre había tenido- el correlato simbólico de la malla política efectiva, elaborando en 1817 un "Orden provisorio para las concurrencias en que el Supremo Gobierno ha de presentarse con las autoridades: marcha y lugares que han de tomar en los templos". Conforme a estas disposiciones, siempre que el gobierno asistiese a alguna "función clásica", como aniversarios de la independencia o Corpus Christi, el cortejo oficial que se dirigía desde el palacio a la catedral, debía pasar entre los batallones montados, que estarían "haciendo calles". La retaguardia del acompañamiento sería cerrada por una escolta de 30 granaderos a caballo, con su respectiva trompeta, mientras que otros Granaderos, en este caso de infantería, se ubicarían, cerca de la puerta del templo para brindar los honores correspondientes. Es interesante notar el orden de distribución que se estipulaba para dicha comitiva oficial, con clara preeminencia de los estamentos uniformados, en consonancia con

\footnotetext{
79 "Viva el Rey". Gazeta del Gobierno de Chile, tomo 2${ }^{\circ}$, n 3. Santiago, 26-III-1816, pp. 173-175.

${ }^{80}$ Ibidem, tomo $1^{\circ}, \mathrm{n}^{\circ} 29$, Santiago, 1-VI-1815, pp. 286-287.

${ }^{81}$ ZAPIOLA, 1974, pp. 6 Y 241.
} 
la efervescencia de la reciente guerra -que todavía no terminaba en las provincias del sur- $\mathrm{y}$, por lo tanto, aún lejos de un organigrama más cívico-republicano.

La disposición de 1817 estipulaba, de esta forma, que el cortejo se compondría de tres columnas. El director supremo debía ubicarse en la del centro y detrás de él irían el mayor de la Plaza, los edecanes y su capellán; en una fila posterior, los ayudantes de los generales y la escolta montada. En las dos columnas laterales debían ubicarse el conjunto de la alta burocracia y el clero, aunque siempre reservando las vanguardias destacadas a la alta oficialidad. De esta manera y "tomando por su grado el lugar que se acerque más al Gobierno", desfilarían los comandantes en jefe, los coroneles y el auditor general, seguidos luego por los ministros de Estado y el tribunal de justicia. En la otra columna, por la derecha, caminarían los generales, seguidos por los comisarios, el intendente de Moneda, los ministros de Tesorería, el Tribunal de Cuentas, el Consulado y, finalmente, el Cabildo, que iría precedido por el intendente. Un orden similar se tendría en los asientos del templo ${ }^{82}$.

Durante ese año y el siguiente esta tendencia se mantendrá, produciéndose una presencia permanente de batallones y de imponentes escoltas montadas para rodear a las principales autoridades, así como constantes disposiciones oficiales ordenando descargas de artillería en los eventos locales, tanto para aniversarios propiamente militares como también para los religiosos. Además, se realizaban para realzar la llegada de las principales figura castrenses o del propio director supremo ${ }^{83}$.

El fundamento castrense de la naciente república quedó claro también en el calendario de aniversarios que comenzaron a celebrarse como hitos legitimadores de la memoria oficial ${ }^{84}$. Un breve recorrido por las fuentes de esos años nos muestra que, además de las principales fiestas del calendario católico y aquellas relacionadas con las advocaciones protectoras privilegiadas por los patriotas, la naciente república castrense se empeñó en fijar el festejo de algunos hitos fundadores vinculados con batallas exitosas de la reciente guerra. Aniversarios como el paso del ejército por los Andes o las batallas de Chacabuco y Maipú son celebradas con grandes desfiles y demostraciones de artillería ${ }^{85}$.

Incluso el establecimiento de la junta de 1810 , pese a su carácter originalmente cívico, será cooptado como hito fundacional por el nuevo régimen, en forma complementaria a las batallas mencionadas y revestido con el mismo ropaje estético a la hora de desplegar el fasto público. Así, por ejemplo, durante el 18 de septiembre de 1817 la plaza de Santiago estuvo desde el amanecer copada por numerosos batallones de caballería e infantería, con sus armas cargadas para hacer las respectivas detonaciones a la salida del sol. Doce cañones (seis chilenos y seis rioplatenses) hicieron lo suyo, mientras que desde el fuerte ubicado en la cima del cerro Santa Lucía se

${ }^{82}$ Orden del día de la plaza militar de Santiago. Santiago, 1-IV-1817. Archivo O’Higgins, XXIII, pp. 19-21.

${ }^{83}$ Véanse, por ejemplo, las órdenes del día de la plaza militar de Santiago, de 3, 4 y 30 de abril, y 12 de mayo de 1817. Ibídem, pp. 21-22, 34 y 37.

${ }^{84}$ Peralta, 2007; Pinto Vallejos - Valdivia Ortíz de Zárate, 2009.

${ }^{85}$ Véanse, por ejemplo, las órdenes del día de la plaza militar de Santiago. Santiago, 9 y 15-VII1817; 5-X-1817; 7, 22 y 23-XII-1817; 13-II-1818; 14-III-1818 y 27-V-1818, Archivo O’Higgins, XXIII, pp. $74-75,79-80,119,165-166,178-179,194,202-203$ y $245-246$. 
descargaban 40 tiros por parte de la batería apostada en un pequeño fuerte que allí se había construido durante la restauración monarquista ${ }^{86}$.

La situación resultó similar para la celebración del 12 de febrero del año siguiente, primer aniversario de la batalla de Chacabuco, que estuvo precedida en los meses anteriores por numerosas ocasiones en que se desplegaron desfiles de soldados para festejos marcados fundamentalmente por un tono militar ${ }^{87}$. El aniversario de Chacabuco fue, entonces, una fiesta esencialmente castrense, lo que es especialmente importante pues fue el momento, además, en que se proclamó oficialmente la independencia de Chile. Para este efecto se dispusieron dos tablados -en la plaza principal y en la de San Francisco- siguiendo la fórmula empleada por los últimos Borbones para los ritos oficiales de las proclamaciones reales. El primero de ellos, destinado tradicionalmente para acoger a las principales autoridades políticas y judiciales, estaba ahora monopolizado por la presencia de los cadetes de la flamante Academia Militar fundada por O'Higgins. La artillería, armada con fusiles, formaba una línea que cubría el trecho entre este entarimado y el palacio de gobierno, disponiendo en las puertas de este último una serie de cañones para hacer las salvas correspondientes. En la "orden del día" de la plaza militar de la capital podemos ver los numerosos batallones que se iban disponiendo en la plaza y copando las principales calles aledañas, hasta el segundo tablado de La Cañada. En medio de ellos debía circular el director supremo y su cortejo, mientras se le presentaban armas y las bandas batían paso de marcha ${ }^{88}$. Este último elemento, señalado al pasar, nos parece fundamental a la hora de imaginar el avance de estos cortejos oficiales, que ahora debían seguir el ritmo acompasado del paso militar.

\section{REFERENCIAS BIBLIOGRÁFICAS}

AA.VV.

1898 Boletín de las leyes $i$ decretos del gobierno. Tomo 1 (1810-1814). Santiago. Imprenta Nacional.

1950 Colección de historiadores y documentos relativos a la Independencia de Chile. Vol. XXXV. Santiago. Imprenta Cervantes.

Allendesalazar ArRau, Jorge de

1962 "Ejército y milicias del reino de Chile (1737-1815)". Boletín de la Academia Chilena de la Historia. Santiago. n 66, pp. 102-178.

\footnotetext{
${ }^{86}$ Orden del día de la plaza militar de Santiago. Santiago, 17-IX-1817. Ibídem, pp. 110-111.

${ }^{87}$ Véanse, por ejemplo, las órdenes del día de la plaza militar de Santiago de 10 y 24-I-1818 y 1-II1818. Ibídem, pp. 184-185 y 189-190.

${ }^{88}$ Orden del día de la plaza militar de Santiago, 11-II-1818, Ibídem, p. 193. Formas similares asumieron las celebraciones por la victoria de Maipú y la independencia de las Provincias Unidas del Río de la Plata: Ordenes del día de la plaza militar de Santiago. Santiago, 4 y 24-V-1818; 8-VII-1818. Ibidem, pp. 230-231, 243 y 262.
} 
AndúJar CAstillo, Francisco

1991 Los militares en la España del siglo XVIII. Un estudio social. Granada. Universidad de Granada.

ARCHER, Christon

1983 El ejército en el México borbónico, 1760-1810. México. Fondo de Cultura Económica.

1993 "Militares". En Hoberman, Louisa y Socolow, Susan (eds.). Ciudades y sociedad en Latinoamérica colonial. Buenos Aires. Fondo de Cultura Económica, pp. 215-254.

Barros Arana, Diego

1999-2005 Historia general de Chile [1884-1902]. Santiago. Editorial Universitaria / DIBA. 16 volúmenes.

Borja Medina, Francisco

1984 "La reforma del ejército en Nueva España". Anuario de Estudios Americanos. Sevilla. ${ }^{\circ}$ 41, pp. 315-395.

BRADING, David

1971 Miners and Merchants in Bourbon Mexico, 1763-1810. London. Cambridge University Press.

1991 Orbe indiano. De la monarquía católica a la República criolla, 14921867. México. Fondo de Cultura Económica.

CAMPBell, Leon G.

1978 The military and society in colonial Peru, 1750-1810. Philadelphia. The American Philosophical Society.

CAPEL, Horacio

1983 Los ingenieros militares en España. Repertorio biográfico e inventario de su labor cientifica y espacial. Barcelona. Ediciones de la Universidad de Barcelona.

2005 "Construcción del Estado y creación de cuerpos profesionales científicotécnicos: los ingenieros de la monarquía española en el siglo XVIII". En CÁmara Muñoz, Alicia - Cobos Guerra, Fernando (eds.). Fortificación y frontera marítima. Eivissa. Ajuntament d'Eivissa [ed. en CD].

Cervilla Lozada, Joana

2004 "La Presidencia en Chile: entre la élite local y la guerra de Arauco". En Pardo-Figueroa Thays - Dager Alva (eds.), pp. 29-57.

Chauca García, Jorge

2005 "La defensa de la América meridional durante la segunda mitad del siglo XVIII: entre la amenaza inglesa y el impacto revolucionario francés". En Guimerá Ravina, Agustín y Peralta Ruiz, Víctor (eds.). El equilibrio de los imperios: de Utrecht a Trafalgar. Madrid. Fundación Española de Historia Moderna, pp. 631- 645. 
Contreras Cruces, Hugo

2006 "Las milicias de pardos y morenos libres de Santiago de Chile en el siglo XVIII, 1760-1800". Cuadernos de Historia. Santiago. no 25, pp. 93-117.

Cruz, Isabel

1990 "El traje como signo de los nuevos tiempos: la Revolución Francesa y la moda en Chile, 1800-1820”. En KreBs - Gazmuri (eds.), pp. 179-223.

De Los Ríos, Fernando Antonio

1913 "Varias novedades acontecidas en esta ciudad, las que corren desde el año de 1765”. Revista Chilena de Historia y Geografia. Santiago. no 10, pp. 32-94.

De Ramón, Armando

1992 Santiago de Chile (1541-1991). Historia de una sociedad urbana. Madrid. Mapfre.

GASCÓN, Margarita

1993 "The Military of Santo Domingo, 1720-1764". Hispanic American Historical Review. Durham. vol. 73: 3, pp. 431-452.

GÁlvez, José Francisco

1999 "Burócratas y militares en el siglo XVIII". En O'PHELAN Godoy, Scarlett (ed.). El Perú en el siglo XVIII. La era borbónica. Lima. Pontificia Universidad Católica del Perú - Instituto Riva-Agüero, pp. 243-262.

GómEZ De VIDAURRE, Felipe

1789 Historia geográfica, natural y civil del reino de Chile. En Colección de historiadores de Chile y de documentos relativos a la historia nacional. Segunda serie (1706-1809). Santiago. Sociedad Chilena de Historia y Geografía - Academia Chilena de la Historia, vols. XIV y XV.

GóngORA, Mario

1998 Estudios sobre la historia colonial de Hispanoamérica. Santiago. Universitaria.

HERnÁNDEZ PonCE, Roberto

1984 "La Guardia Nacional de Chile. Apuntes sobre su origen y organización, 1808-1848". Historia. Santiago. no 19, pp. 53-114.

JuAn, Jorge y UlloA, Antonio de

1748 Relacion historica del viage a la America meridional. Madrid. Por Antonio Marín. 3 tomos.

KREBS, Ricardo y GAZMURI Cristian (eds.)

1990 La Revolución Francesa y Chile. Santiago. Universitaria.

KUETHE, Allan

1978 Military reform and society in New Granada, 1773-1808. Gainesville. The University Presses of Florida. 
2005 "Las milicias disciplinadas en América". En Kuethe, Allan - MarchenA FERNÁNDEZ, Juan (eds.). Soldados del rey. El ejército borbónico en América colonial en vísperas de la Independencia. Castelló de la Plana. Universitat Jaume I, pp. 101-125.

LEÓN, Leonardo

1998 "Reglamentando la vida cotidiana en Chile colonial, 1760-1768". Valles. Revista de Estudios Regionales. La Ligua (Chile). no 4, pp. 47-75.

2000 "La construcción del orden social oligárquico en Chile colonial: la creación del Cuerpo de Dragones, 1758". En Retamal, Julio (coord.). Estudios coloniales. I. Santiago. Universidad Andrés Bello, pp. 183-194.

2002 "Reclutas forzados y desertores de la Patria: el bajo pueblo chileno en la guerra de la Independencia, 1810-1814". Historia. Santiago. n 35, pp. 251-297.

LeÓN GARCía, María del Carmen

2006 "Reconocimiento territorial y obra cartográfica de los ingenieros militares en Nueva España (segunda mitad del siglo XVIII)". Scripta Nova. Revista Electrónica de Geografía y Ciencias Sociales. Barcelona. nº 218. Versión digital disponible en: www.ub.es/geocrit/sn/sn-218-55.htm.

LYNCH, John

1981 Gobierno y Sociedad. El Régimen de Intendencias en el Perú 1784-1814. Lima. Pontificia Universidad Católica del Perú.

Marchena FernándeZ, Juan

1977 "La primera Academia de Ingenieros en América. Cartagena de Indias, 1714". Ejército. Madrid. no 477, pp. 23-30.

1992 Ejército y milicias en el mundo colonial americano. Madrid. MAPFRE.

MARTínEz, Melchor (fray)

1815 Memoria histórica sobre la revolución de Chile desde el cautiverio de Fernando VII hasta 1814 [1815]. Santiago. Biblioteca Nacional. 2 tomos.

Mc Alister, Lyle N.

1957 The "fuero militar" in New Spain, 1764-1800. Gainesville. University of Florida Press.

Medina, José Toribio

1952 Cosas de la Colonia. Apuntes para la crónica del siglo XVIII en Chile. Santiago. Fondo Histórico y Bibliográfico José Toribio Medina.

1963 Biblioteca hispano-chilena (1523-1817). Santiago. Fondo Histórico y Bibliográfico José Toribio Medina. 3 volúmenes.

1970 Estudios sobre literatura colonial de Chile. Santiago. Fondo Histórico y Bibliográfico José Toribio Medina. 2 volúmenes.

Meza Villalobos, Néstor

1957 La actividad política del reino de Chile entre 1806 y 1810. Santiago. Universidad de Chile. 
Olaguer Feliú, Manuel

1989 Relación de lo ocurrido en el Reyno de Chile desde el 25 de mayo de 1810 hasta la erección de su Junta gubernativa [1810]. Santiago. Instituto O’Higginiano.

Ossa SANTA Cruz, Juan Luis

[Inédito] "La criollización de un ejército periférico. Chile, 1768-1810".

Pardo-Figueroa Thays, Carlos y Dager Alva, Joseph (eds.)

2004 El virrey Amat y su tiempo. Lima. Pontificia Universidad Católica del Perú - Instituto Riva-Agüero.

Peralta, Paulina

2007 Chile tiene fiesta! El origen del 18 de septiembre (1810-1837). Santiago. LOM.

Pérez García, José

ca.1810 Historia natural, militar, civil y sagrada del reino de Chile en su descubrimiento, conquista, gobierno, población, predicación evangélica, erección de catedrales y pacificación. En Colección de historiadores de Chile y de documentos relativos a la historia nacional. Segunda serie (1706-1809). Santiago. Sociedad Chilena de Historia y Geografía y Academia Chilena de la Historia. vols. XXII y XXIII.

Pinto Vallejos, Julio y Valdivia Ortíz de Zárate, Verónica

2009 ¿Chilenos todos? La construcción social de la nación (1810-1840). Santiago. LOM.

RaGas, José F.

2004 "El discreto encanto de la milicia. Ejército y sociedad en el Perú borbónico". En Pardo-Figueroa Thays - Dager Alva (eds.), pp. 209-228.

Rolle, Claudio

1990 "Los militares como agentes de la revolución". En KreBS - GAZMURI (eds.), pp. 277-302.

SAgRedo Baeza, Rafael y González Leiva, José Ignacio

2004 La expedición Malaspina en la frontera austral del imperio español. Santiago. Editorial Universitaria / DIBAM - Centro de Investigaciones Diego Barros Arana.

Talavera, Manuel Antonio

1937 Revoluciones de Chile. Discurso histórico, diario imparcial de los sucesos memorables acaecidos en Santiago de Chile desde el 25 de mayo de 1810 hasta el 20 de noviembre de 1811, por un vecino testigo ocular, en defensa de la verdad, del honor y conducta de muchos fieles ciudadanos [1811]. Santiago. Talleres Gráficos "Condor". 
UNDURRAGA, Verónica

2008 Los rostros del honor. Identidades, representaciones y prácticas culturales de los grupos medios y populares en el Santiago del siglo XVIII. Tesis de Doctorado en Historia. Santiago. Pontificia Universidad Católica de Chile.

Valenzuela Márquez, Jaime

1992 "La percepción del tiempo en la Colonia: poderes y sensibilidades". Mapocho. Santiago. $\mathrm{n}^{\circ}$ 32, pp. 225-244.

2001 Las liturgias del poder. Celebraciones públicas y estrategias persuasivas en Chile colonial (1609-1709). Santiago. Dirección de Bibliotecas, Archivos y Museos - Centro de Investigaciones Diego Barros Arana / LOM.

2005 "Poder y pirotecnia, artesanos y mapuches: apogeo barroco de las proclamaciones reales en Santiago de Chile, 1760-1789". Colonial Latin American Historical Review. Albuquerque. ${ }^{\circ}$ 14:1, pp. 49-78.

Vergara, Sergio

1993 Historia social del Ejército de Chile. Santiago. Universidad de Chile. 2 volúmenes.

ViLlalobos, Sergio

1995 Vida fronteriza en la Araucanía. El mito de la guerra de Arauco. Santiago. Andrés Bello.

2000 Historia del pueblo chileno. volumen IV. Santiago. Universitaria.

ZAPIOLA, José

1974 Recuerdos de treinta años (1810-1840). Buenos Aires. Francisco de Aguirre. 